\title{
TOLERANCE TO OZONE IN EMPHYSEMATOUS RATS
}

\author{
Ziro NAMBU* and Eiji YoKoYAMA* \\ 肺気腫ラットを用いたオゾン耐性実験 \\ 南 部 滋 郎*, 横 山栄 二*
}

\begin{abstract}
Pulmonary emphysema was induced in rats by a single intratracheal instillation of swine pancreatic elastase. After adequate development of the pulmonary emphysema, the animals were initially exposed to $1.9 \mathrm{ppm}$ ozone for $3 \mathrm{hrs}$, and 3 days later, challenge-exposed to $5.1 \mathrm{ppm}$ ozone for $3 \mathrm{hrs}$ and immediately sacrificed to investigate the extent of the development of tolerance to ozone judged by the formation of edema. Although the body weights of the pulmonary emphysematous rats were the same as those of the saline-treated control rats, the lung weights of the former were heavier. The extent of the edema formation by ozone and of the tolerance to ozone of the pulmonary emphysematous rats seemed to be quite similar to those of the saline-treated control rats. On the other hand, although the exposure of the salinetreated control rats to $1.9 \mathrm{ppm}$ ozone for $3 \mathrm{hrs}$ resulted in an increase in lung weight without edema 3 days after the exposure, the pulmonary emphysematous rats did not show such a response.
\end{abstract}

\section{INTRODUCTION}

It is well known that ozone is an occupational hazard. Arc welders, employees in the cabins of airplanes and patients taking sunray treatments are often exposed to a relatively high concentration of ozone. Recently, it has been reported that not only laboratory animals ${ }^{1,2)}$ but also humans ${ }^{3-6)}$ can develop tolerance or adaptation to ozone. In humans, the term adaptation is preferable to tolerance, because repeated exposures to low concentration of ozone were employed to induce tolerance and the same concentration of ozone was used for testing the induction of tolerance and designs of the exposure are applicable to humans and physiological measurements are employed to detect tolerance in place of measurements of survival or pulmonary edema.

It is suspected that smokers and the aged are rather sensitive to irritants, and it appears that they have a high risk of pulmonary emphysema. The question arises whether emphysema affects

\footnotetext{
* Department of Industrial Health, Institute of Public Health

Received for publication, December 21, 1984

* 国立公案街生院学做街生学部 昭和59年12月21日受付
}

pulmonary responses to ozone including the development of adaptation in humans. Because of the difficulty of making such experiments in humans and because of the recent establishment of an animal model of pulmonary emphysema, ${ }^{7,8)}$ the question can be experimentally examined using rats.

\section{MATERIALS AND METHODS}

Specific pathogen free, male Wistar strain rats, 6 weeks old, were kept with laboratory chow and tap water ad libitum in an air-conditioned (22$24^{\circ} \mathrm{C}$ ) room supplied with HEPA-filtered air under controlled lighting conditions ( $12 \mathrm{hr}$ light and 12 hr dark cycle).

Forty-five-day old rats weighing about $200 \mathrm{~g}$ were anesthetized with ethyl ether and intratracheally injected elastase (Worthington, $9.4 \mathrm{u} / \mathrm{mg}, 6.5 \mathrm{u} / 0.25$ $\mathrm{ml}$ saline/rat) as follows: the animal was hung upward at a $34^{\circ}$ angle and a part of a stainless steel tube (1 $\mathrm{mm}$ in external diameter, $95 \mathrm{~mm}$ long) was inserted into the trachea through the oral cavity. After the animal's breath was confirmed by observing the movement of a paper string at the end of the tube, the enzyme solution was injected through a fine plastic tube inserted into the stainless steel tube. Control animals were similarly treated but injected with saline alone. 
Table 1. Body weights and lung weights of the elastase- and saline-treated rats.

\begin{tabular}{|c|c|c|c|c|c|c|c|}
\hline Group & $N$ & $\begin{array}{c}\text { Body weight } \\
\text { (g) }\end{array}$ & $\begin{array}{c}\text { LWW } \\
(\mathrm{g})\end{array}$ & $\underset{(g)}{\text { LDW }}$ & $W-D$ & $\begin{array}{c}(W-D) / W \\
(\%)\end{array}$ & $W / D$ \\
\hline $1-S$ & 7 & $410 \pm 36$ & $1.24 \pm 0.07$ & $0.248 \pm 0.011$ & $0.99 \pm 0.05$ & $79.9 \pm 0.3$ & $4.99 \pm 0.08$ \\
\hline $1-\mathrm{E}$ & 8 & $405 \pm 24$ & $1.43^{* *} \pm 0.10$ & $0.288^{* *} \pm 0.020$ & $1.14^{* *} \pm 0.08$ & $79.8 \pm 0.3$ & $4.96 \pm 0.08$ \\
\hline $2-S$ & 7 & $437 \pm 30$ & $1.44^{* *} \pm 0.12$ & $0.283^{* *} \pm 0.026$ & $1.15^{* *} \pm 0.10$ & $80.3 \pm 0.3$ & $5.08 \pm 0.08$ \\
\hline $2-\mathrm{E}$ & 7 & $425 \pm 20$ & $1.50 \pm 0.03$ & $0.300 \pm 0.007$ & $1.20 \pm 0.03$ & $80.0 \pm 0.3$ & $5.00 \pm 0.06$ \\
\hline $3-S$ & 8 & $438 \pm 18$ & $1.70 \pm 0.23$ & $0.298 \pm 0.016$ & $1.40 \pm 0.22$ & $82.2 \pm 1.9$ & $5.68 \pm 0.65$ \\
\hline $3-E$ & 7 & $450 \pm 12$ & $2.01 \pm 0.38$ & $0.356 \# \# \pm 0.032$ & $1.70 \pm 0.36$ & $82.5 \pm 1.8$ & $5.76 \pm 0.66$ \\
\hline 4-S & 8 & $417 \pm 28$ & $2.61 \pm 0.47$ & $0.364 \pm 0.057$ & $2.25 \pm 0.42$ & $86.0 \pm 1.2$ & $7.18 \pm 0.67$ \\
\hline 4-E & 8 & $415 \pm 27$ & $2.86 \pm 0.33$ & $0.404 \pm 0.035$ & $2.46 \pm 0.31$ & $85.8 \pm 1.1$ & $7.09 \pm 0.55$ \\
\hline
\end{tabular}

**: $p<0.01$ vs. $1-\mathrm{S}$, \#\#: $p<0.01$ vs. 3-S. Group 1: not exposed to ozone, Group 2: initially exposed to 1.9 ppm ozone for $3 \mathrm{hrs}$ alone, Group 3: initially exposed to $1.9 \mathrm{ppm}$ ozone and 3 days later challenge-exposed to $5.1 \mathrm{ppm}$ ozone for $3 \mathrm{hrs}$, Group 4: challenge-exposed to $5.1 \mathrm{ppm}$ ozone for $3 \mathrm{hrs}$ alone. LWW: lung wet weight, LDW: lung dry weight, $W-D$ : lung water content, $(W-D) / W$ : relative lung water content, $W / D$ : ratio of lung wet weight to lung dry weight. E: elastase-treated rats, $\mathrm{S}$ : saline-treated control rats. N: number of animals used.

The elastase-treated and the saline-treated rats were kept another 50 days to develop adequate pulmonary emphysema, ${ }^{8}$ ) and divided into 4 groups. Group 1; Not exposed to ozone, Group 2; Initially exposed to $1.9 \mathrm{ppm}$ ozone for $3 \mathrm{hrs}$ alone. Group 3; Initially exposed to $1.9 \mathrm{ppm}$ ozone for $3 \mathrm{hrs}$ and 3 days later challenge-exposed to $5.1 \mathrm{ppm}$ ozone for $3 \mathrm{hrs}$. Group 4; Challenge-exposed to 5.1 ppm ozone for $3 \mathrm{hrs}$ alone. Group 2 and Group 3 were initially exposed the day of the grouping and Group 3 and Group 4 were challenge-exposed 3 days after the initial exposure. All the animals were immediately sacrificed. The details of the experimental design of tolerance, the methods of the exposure of animals to ozone and the measurements of lung weights have been described elsewhere. ${ }^{2)}$

\section{RESULTS AND DISCUSSION}

It has been demonstrated that the lungs of rats treated with intratracheal elastase 50 days earlier were apparently emphysematous, ${ }^{8}{ }^{8}$ resembling human lungs with panacinar emphysema.

Body weights and lung weights of the elastasetreated and the saline-treated rats are shown in Table 1. Though the growth of the animals was affected at first by the elastase treatment, there was no significant difference between the body weights of the elastase-treated and of the saline-treated rats.

It was found that the lung wet weight (LWW) and dry weight (LDW) and the lung water content (LWC) of the elastase-treated rats in Group 1 increased significantly compared to the control rats and that relative lung water content (RLWC) and wet to dry ratio of the lung weight (W/D) of the former were the same as those of the latter. The gain in lung weights of the elastase-treated rats has also been reported by others ${ }^{9}$ but its cause is unknown. Had inflammation still occurred? This possibility seemed to be excluded by the results of lung function and morphology.8) It was unlikely that severe lung fibrosis occurred, because the contents of collagen and elastin in lungs of the animals differed little from controls. ${ }^{10}$ ) There might be compensatory proliferation of the lung during the development of pulmonary emphysema. It was reported that there was increased mitotic activity during an early lesion by the elastase treatment.?)

The initial exposure of the saline-treated rats resulted in a significant increase of LWW, LDW and LWC extending to the level of the elastasetreated rats in Group 1, and their RLWC and W/D remained unchanged, suggesting little edema formation and a sort of cell proliferation. On the other hand, such effects of the initial exposure were not found in the elastase-treated rats. It has been reported that pulmonary proliferation developed in normal rats after initial exposure to ozone.1) These results suggest that pulmonary emphysematous rats are less susceptible to low concentrations of ozone than normal rats.

On the other hand, elastase-treated and salinetreated rats showed the same response to the challenge-exposure, and no difference of edema formation was found between them. This and the 
former results indicate that normal rats have a lower threshold of susceptibility to ozone than pulmonary emphysematous rats judging from the gain of pulmonary weight and that both of them responded similarly to high concentration of ozone.

Lung dry weight of the elastase-treated rats in Group 3 was significantly greater than that of the saline-treated rats, but all other measured and calculated values were the same. The gain of lung weights, RLWC and $W / D$ in Group 3 was less than in Group 4 and larger than in Group 2. It can be concluded from these results that a similar partial tolerance ${ }^{2}$ can be induced in both elastasetreated rats and saline-treated rats.

Because of the enlargement of the respiratory air space of the lungs with destruction of their walls in the pulmonary emphysematous rats treated with elastase, it was anticipated that the exposure-effectrelationship would change.

However, excepting for the greater lung weights without edema measured in the Group 2 controls, the formation of edema and the development of tolerance to ozone appeared to be similar in all the rats. It remains to be shown whether a kind of compensatory proliferation of pulmonary epithelial cells occurs during the development of pulmonary emphysema.

Acknowledgments. This work was partly supported by the lump-sum budget of Environmental Research of Governmental Institute, Japan 1983. We are very grateful to Mrs. Hatsuko Arakawa for her assistance.

\section{REFERENCES}

1) National Research Council. Committee on Medical and Biologic Effects of Environmental Pollutants: Toxicology. In Ozone and Other Photochemical Oxidants, 323-387, National Academy of Sciences, Washington, D.C., 1977.

2) Nambu, Z. and Yokoyama, E.: Ozone injury and tolerance in reference to pulmonary edema, Bull. Inst. Publ. Health, 27: 53-57, 1978.

3) Hackney, J.D., Linn, W.S., Mohler, J.G. and Collier, C.R.: Adaptation to short-term respiratory effects of ozone in men exposed repeatedly, J. Appl. Physiol., 43: 82-85, 1977.

4) Farrell, B.P., Kerr, H.D., Kulle, T.J., Sauder, L.R. and Young, J.L.: Adaptation in human subjects to the effects of inhaled ozone after repeated exposure, Am. Rev. Respir. Dis., 119: 725-730, 1979.

5) Gliner, J.A., Horvath, S.M. and Folinsbee, L.J.:
Preexposure to low ozone concentrations does not diminish the pulmonary function response on exposure to higher ozone concentrations, Am. Rev. Respir. Dis., 127: 51-55, 1983.

6) Kulle, J.H., Milman, J.H., Sauder, L.R., Kerr, H.D., Farrell, B.P. and Miller, W.R.: Pulmonary function adaptation to ozone in subjects with chronic bronchitis, Environ. Res., 34: 55-63, 1984.

7) Lucey, E.C.: Experimental emphysema, Clin. Chest Med., 4: 389-403, 1983.

8) Yokoyama, E. and Kyono, Y.: Lung function and morphology of the rats administered elastase intratracheally, Jpn. J. Thor. Dis., 21: Suppl. 48, 1983.

9) Harkema, J.R., Mauderly, J.L., Gregory, R.E., and Pickrell, J.A.: A comparison of starvation and elastase models of emphysema in the rat, Am. Rev. Respir. Dis., 129: 584-591, 1984.

10) Nambu, Z., Ichikawa, I. and Yokoyama, E.: Effects of exposure to ozone on lung and blood biochemistry in emphysematous rats, Proceedings of the 25th annual meeting of the Japan Society of Air Pollution, p. 554, 1984.

\section{和 文 要 旨}

オゾンに対する耐性発現の現象はよく知られたことで あるが，正常動物を用いた奏験がほとんどであり，病態 モデル動物を用いた例は数少ない。老化和よび契湮に伴 い肺気腫が生じることを考党，眆気腫がどのようにオン゙ ン耐性の発現に影響を与えるかを調べた.

体重 $200 \mathrm{~g}$ の 7 週龄の Wistar 系雄ラットの気管内に, 6.5 単位豚脺葴エラスターゼ (Worthington, $9.4 \mathrm{u} / \mathrm{mg}$ ) 含有 $0.25 \mathrm{ml}$ 生理食塩水を経口的に注入し，対照群には 生理食塩水のみを注入し，その後50日間飼育し, 肺気腫 ラットを得た. このラットをオンンに前暴露 $(1.9 \mathrm{ppm}$, $3 \mathrm{hr})$ し，その 3 日後にオソンに挑戦暴露 $(5.1 \mathrm{ppm}, 3 \mathrm{hr}$ し，暴露直後にネンブタール麻酔下に脱血死させ，肺湿 乾重量を測定した.

オソンKまったく暴露されていない肺気尰ラットの肺 湿乾重量, 肺水分含量は対照群より大 $(p<0.01)$ であっ たが, 肺相対水分含量, 肺湿乾重量比は無変化であった。 前暴露後 3 日目に対照群の肺湿乾重量, 肺水分含量が 增加 $(p<0.01)$ するか子, 肺相対水分含量, 眠湿乾重量比 は無変化であった. 一方肺気腫ラットは前暴露で肺重量 諸值に影響を受けなかった。

挑戦暴露のみを受けたラットは対照群も肺気腫群も同 程度に肺水腫となった。

前暴露後 3 日目に挑戦暴露を受けた肺気尰ラットの肺 乾燥重量は対照群に比べて大 $(p<0.01)$ であったが，他 の肺重量諸值は刘照群に同じで, 両群とも中程度の肺水 
腫状態となり，肺気腫ラットは対照正常ラットと同程度 のオソンン耐性を示すことが認められた。

以上より，肺気尰ラットの肺は対照より大であるこ と $(15 \%)$, 対照ラットの肺の增大をらながす $1.9 \mathrm{ppm}$
オソンン 3 時間暴露では影響を受けないこと，高濃度のオ ゾン (5.1 ppm, $3 \mathrm{hr})$ に対しては対照と同程度の肺水重 になること，耐性発現す対照と同程度起こることが知え た.

Reprint requests to Department of Industrial Health, The Institute of Public Health, 4-6-1 Shirokanedai, Minato-ku, Tokyo, $108 \mathrm{Japan}$ (Z. Nambu) 著者への通信先 : 南部滋郎, 宁108 東京都 港区白金台 4-6-1 国立公臬衛生院労偅衛生学部 